\title{
EFFECT OF LEVELS, DOSES OF NITROGEN FERTILIZER AND SEEDING RATES ON YIELD AND QUALITY OF SUGARCANE Ahmed F.I. Gadallah
}

\section{ABSTRACT}

Sugar Crops Res. Inst., Agric. Res. Center, Giza, Egypt

Two field experiments were conducted at Shandaweel Agricultural Research Station, Sohag Governorate, Egypt (latitude of $2661^{\circ} \mathrm{N}$, longitude of $3152^{\circ} \mathrm{E}$ and altitude of $72 \mathrm{~m}$ above sea level) in 2016/2017 and 2017/2018 seasons to assess the effect of levels and number of doses of nitrogen fertilizer as well as seed rates on yield and quality of sugarcane. This work included 27 treatments, represent the combinations among three rates of seeds [1.0, 1.5 and 2.0 rows of 3-budded cane cuttings (25200, 37800 and 50400 buds/fed)], three levels of $\mathrm{N}(180,210$ and $240 \mathrm{~kg}$ $\mathrm{N} /$ fed), and three $\mathrm{N}$ doses (each $\mathrm{N}$ level was split and applied as 2, 3 and 4 equal doses). The sugarcane cultivar namely G. 2004-27 (Giza-4) was used as a planting material. A randomized complete block design (RCBD) was used a split-split plot arrangement and replicated three times. The main-plots were devoted for seed rates, $\mathrm{N}$ levels were randomly applied in the sub plots, while number of $\mathrm{N}$ doses were distributed in the sub-sub plots, in both seasons.

The results revealed that seed rates had a significant effect on all studied traits of sugarcane at harvest time. Planting sugarcane using 2.0 rows of cuttings (50400 buds/fed) improved millable cane height, number of millable canes/fed, cane and sugar yields/fed, while significant improvements in millable cane diameter, millable cane weight, brix $\%$, sucrose $\%$ and sugar recovery $\%$ was recorded in case of growing sugarcane using 1.0 row ( 25200 buds/fed), in both seasons.

Increasing $\mathrm{N}$ fertilizer level to $240 \mathrm{~kg} \mathrm{~N} / \mathrm{fed}$ resulted a significant increase in millable cane height, diameter, millable cane weight, number of millable canes/fed, cane and sugar yields/fed, while the application of $210 \mathrm{~kg} \mathrm{~N} / \mathrm{fed}$ led to a significant increase in brix, sucrose and sugar recovery percentages, in both seasons.

The results indicated that increasing the number of $\mathrm{N}$ doses from 2 to 4 had significant positive effects on millable cane height, diameter, millable cane weight, number of millable canes/fed, cane and sugar yields/fed, along with brix, sucrose, and sugar recovery percentages, in both seasons.

Under conditions of this work, it was found that growing Giza-4 sugarcane variety using 2.0 rows of cane setts (50400 buds/fed) with add $240 \mathrm{~kg}$ N/fed into 4doses can be recommended to get the maximum cane and sugar yields.

\section{INTRODUCTION}

Sugarcane G. 2004-27 (Giza-4) variety is a newly registered one. So, finding out the recommendation package required for growing it becomes of paramount importance to get the its highest cane and sugar yield. Among the agricultural treatments, this work will begin with studying the appropriate seed rate as well as levels and number of doses of nitrogen fertilizer.

Fayoum J. Agric. Res. \& Dev., Vol. 34, No.1, January, 2020 
Many researchers in Egypt and most countries of the world showed that cane yield increase with increasing seeding rate, probably due to the maximum utilization of growth factors as solar radiation, water and nutrients by an optimal number of cane plants, which will reflected in more photosynthesis and dry matter accumulation in cane stalks. In this respect, Ismail, et al. (2008) indicated that growing sugarcane using 50400 buds/fed gave the highest number of millable canes, stalk height, brix, sucrose, sugar recovery, cane and sugar yields/fed compared to 25200 and/or 37800 buds/fed. Hasan, et al. (2009) found that stalk height, diameter, brix, sucrose, sugar recovery, cane and sugar yields/fed differed significantly, as a result of planting sugarcane using 1.5, 2.0 and 2.5 rows of cane cuttings/fed. Shalaby, et al. (2011) showed that planting sugarcane with 50400 buds/fed recorded higher values of stalk height, sucrose, sugar recovery, millable canes/fed, cane and sugar yields/fed, while using 37800 buds/fed resulted in higher stalk diameter and brix. El-Geddawy, et al. (2015) reported that drilling two rows of sugarcane setts attained significantly the highest values of stalk length, diameter, number of millable canes/fed, brix, sucrose, cane and sugar yields/fed. Bekheet and Abd El-Aziz (2016) indicated that increasing seeds rate from 1.5 to 2.0 drills produced significant increases in stalk height, diameter, number of millable canes, brix, sucrose, cane and sugar yields/fed. Makhlouf, et al. (2016) found that planting sugarcane by 37800 buds/fed produced higher stalk diameter and stalk fresh weight, while planting it by 50400 buds/fed attained the highest brix, sugar recovery, number of millable canes/fed, cane and sugar yields/fed.

It is well known as a fact that nitrogen is an essential nutrient in building up plant organs. Concerning nitrogen fertilization levels, Osman, et al. (2010) found that increasing $\mathrm{N}$ levels to $240 \mathrm{~kg} \mathrm{~N} /$ fed recorded the highest stalk length, diameter, number of millable canes, brix \%, cane and sugar yields/fed, while sucrose $\%$ and sugar recovery\% decreased significantly. El-Gedawwy, et al. (2012) found that increasing $\mathrm{N}$ levels to $230 \mathrm{~kg} \mathrm{~N} /$ fed produced the highest stalk height, diameter, stalk fresh weight, number of millable canes, brix, sucrose, sugar recovery, cane and sugar yields/fed. Bekheet and Abd El-Aziz (2016) showed that raising $\mathrm{N}$ level to $220 \mathrm{~kg} \mathrm{~N} / \mathrm{fed}$ resulted in increases in stalk height, diameter, number of millable canes/fed, cane and sugar yields/fed. Makhlouf, et al. (2016) cleared that increasing $\mathrm{N}$ levels up to $240 \mathrm{~kg} \mathrm{~N} / \mathrm{fed}$ led to significant increases in stalk length, diameter, stalk fresh weight, number of millable canes/fed, cane and sugar yields/fed.

Increasing the number of $\mathrm{N}$-doses given for sugarcane plants could positively affect cane and sugar yields, where splitting the amount of nitrogen fertilizer decreases its leaching beyond root zone, especially when flooding irrigation is used, hence increasing $\mathrm{N}$ utilization by cane plants. In this connection, Pannerselvam and Durai (2004) and Nigade, et al. (2006) found that applying nitrogen in four splits improved growth and yield attributes resulting in higher cane yield compared to three doses. Mokadem, et al. (2008) indicated that increasing number of $\mathrm{N}$-doses attained increases in stalk length, diameter, number of

Fayoum J. Agric. Res. \& Dev., Vol. 34, No.1, January, 2020 
millable canes/fed, sugar recovery\%, cane and sugar yields/fed. Wubale and Girma (2018) studied dividing the applied $\mathrm{N}$ levels into three equal doses (15, 75 and 150 days after planting); two equal doses (75 and 150 days after planting) and a single dose to every $\mathrm{N}$ level at 150 days after planting. They found that the highest length, stalk diameter and cane yield were attained by adding $195 \mathrm{~kg} \mathrm{~N} / \mathrm{ha}$ split into three equal doses.

The aim of the present work was to find out the appropriate seed rate as well as levels and number of doses of nitrogen fertilizer required for growing sugarcane G. 2004-27 (Giza-4) variety to get the highest cane and sugar yields/fed.

\section{MATERIALS AND METHODS}

Two field experiments were conducted at Shandaweel Agricultural Research Station, Sohag Governorate, Egypt (latitude of $2661^{\circ} \mathrm{N}$, longitude of $3152^{\circ} \mathrm{E}$ and altitude of $72 \mathrm{~m}$ above sea level) in 2016/2017 and 2017/2018 seasons to assess the effect of levels and number of doses of nitrogen fertilizer as well as seed rates on yield and quality of sugarcane. This work included 27 treatments, represent the combinations among three rates of seeds [1.0, 1.5 and 2.0 rows of 3-budded cane cuttings (25200, 37800 and 50400 buds/fed)], three levels of $\mathrm{N}(180,210$ and $240 \mathrm{~kg}$ $\mathrm{N} /$ fed), and three $\mathrm{N}$ doses (each $\mathrm{N}$ level was split and applied as 2, 3 and 4 equal doses, which were given after 60, 90, 120 and 150 days from planting, respectively). The sugarcane cultivar namely G. 2004-27 (Giza-4) was used as a planting material. A randomized complete block design (RCBD) was used a split-split plot arrangement and replicated three times. The main-plots were devoted for seed rates, $\mathrm{N}$ levels were randomly applied in the sub plots, while number of $\mathrm{N}$ doses were distributed in the sub-sub plots, in both seasons.

Each plot area was $35 \mathrm{~m}^{2}$ with 5 rows of 7 meters in length and 1.0 meter apart. Sugarcane was planted in the last week of February and harvested after 12 months, in both seasons. Phosphorus fertilizer as calcium super phosphate $(15 \%$ $\mathrm{P}_{2} \mathrm{O}_{5}$ ) was added once during seed bed preparation at the rate $30 \mathrm{~kg} \mathrm{P}_{2} \mathrm{O}_{5} / \mathrm{fed}$. Potassium fertilizer was added once as potassium sulfate $\left(48 \% \mathrm{~K}_{2} \mathrm{O}\right)$ with the $2^{\text {nd }}$ dose of $\mathrm{N}$ fertilizer at the rate of $48 \mathrm{~kg} \mathrm{~K}_{2} \mathrm{O} / \mathrm{fed}$.

Chemical and mechanical properties of the experimental soil are presented in Table (1).

\section{The recorded data:}

The following data were recorded at harvest:

$\begin{array}{ll}\text { 1. Millable cane highest }(\mathrm{cm}) . & \text { 2. Millable cane diameter }(\mathrm{cm}) \text {. }\end{array}$

3. Millable cane weight $(\mathrm{kg})$.

A sample of 20 millable canes from each treatment was taken at random, cleaned and crushed to extract the juice, which was analyzed to determine the following quality traits:

Fayoum J. Agric. Res. \& Dev., Vol. 34, No.1, January, 2020 
Ahmed F.I. Gadallah

1. Brix\% (total soluble solids of juice) was determined using "Brix Hydrometer" according to the method described by "The Chemical Control Lab" of Sugar and Integrated Industries Company (Anonymous, 1981).

2. Sucrose\% was determined using "Sacharemeter" according to A.O.A.C. (2005).

3. Sugar recovery $\%$ was calculated as follows:

Sugar recovery $\%=$ [sucrose $\%-0.4$ (brix $\%$ - sucrose $\%) \times 0.73$ ] . Where $\mathrm{B}=$ Brix reading, $\mathrm{S}=$ Sucrose percentage, 0.4 and 0.73 constants. Yadav and Sharma (1980).

Table (1): Chemical and mechanical properties of the upper 40-cm of the experimental soil

\begin{tabular}{|c|c|c|c|}
\hline \multicolumn{2}{|c|}{ Season } & 2016/2017 & $2017 / 2018$ \\
\hline \multirow{3}{*}{ Mechanical analysis } & Sand\% & 56.34 & 59.20 \\
\hline & Silt & 28.44 & 24.30 \\
\hline & Clay & 15.22 & 16.50 \\
\hline \multicolumn{2}{|c|}{ Soil texture } & Sandy loam & Sandy loam \\
\hline \multirow{12}{*}{ Chemical analysis } & N Available (ppm) & 0.20 & 0.24 \\
\hline & $\mathrm{CaCO}_{3} \%$ & 1.20 & 1.47 \\
\hline & $\mathrm{CO}_{3}$ Meq/100g & 0 & 0 \\
\hline & $\mathrm{HCO}_{3 \mathrm{Meq} / 100 \mathrm{~g}}$ & 0.30 & 0.33 \\
\hline & $\mathrm{CL}_{\mathrm{Meq} / 100 \mathrm{~g}}$ & 0.89 & 0.89 \\
\hline & $\mathrm{SO}_{4}{ }^{\mathrm{Meq} / 100 \mathrm{~g}}$ & 1.02 & 1.13 \\
\hline & $\mathrm{Ca}^{++}{ }_{\text {Meq/100g }}$ & 0.53 & 0.54 \\
\hline & $\mathrm{Mg}^{++}{ }_{\text {Meq/100g }}$ & 0.27 & 0.35 \\
\hline & $\mathrm{Na}^{+}{ }_{\text {Meq/100g }}$ & 1.25 & 1.31 \\
\hline & $\mathrm{K}_{\text {Meq/100g }}^{+}$ & 0.16 & 0.15 \\
\hline & $\operatorname{EC}(d s / m)(1: 5)$ & 0.24 & 0.26 \\
\hline & pH & 7.5 & 7.3 \\
\hline
\end{tabular}

The harvested sugarcanes of the middle three rows of each experimental unit were cut, topped, cleaned up from trash and weighed and counted to estimate the following traits:

1. Number of millable canes/fed. 2. Cane yield/fed (tone).

3. Sugar yield/fed (ton), which was estimated according to the following equation: Sugar yield/fed (ton) $=$ cane yield/fed (ton) $\mathrm{x}$ sugar recovery\%/100.

Statistical analysis:

The collected data were statistically analyzed according to Gomez and Gomez (1984) using the computer "MSTAT-c" statistical analysis package described by Freed, et al. (1989). The least significant differences (LSD) at 0.05

Fayoum J. Agric. Res. \& Dev., Vol. 34, No.1, January, 2020 
level of probability were calculated to compare the differences among means of treatments.

\section{RESULTS AND DISCUSSION}

\section{Millable cane height:}

Data in Table (2) showed that the used seed rates significantly affected millable cane height, in both seasons. Planting sugarcane using 2.0 rows of cane cuttings (50400 buds/fed) increased millable cane height by 14.03 and $3.60 \mathrm{~cm}$, compared to that planted with 1.0 and 1.5 drills of 3-budded setts (25200 and 37800 buds/fed, respectively), in the $1^{\text {st }}$ one, corresponding to 15.02 and $4.50 \mathrm{~cm}$, in the $2^{\text {nd }}$ one. These results may be due to that increasing seed rate resulted in an increase in plants population density, causing mutual shading among plants, and hence directed plants to search for solar radiation (Chang, 1974). Similar results were given by Shalaby, et al. (2011); El-Geddawy, et al. (2015) and Bekheet and Abd El-Aziz (2016).

Increasing $\mathrm{N}$ level given to cane plants to 210 and $240 \mathrm{~kg} \mathrm{~N} / \mathrm{fed}$ led to a significant increase in millable cane height reached $(11.79$ and $20.67 \mathrm{~cm})$ and $(9.80$ and $19.73 \mathrm{~cm}$ ), compared to those provided with $180 \mathrm{~kg} \mathrm{~N} / \mathrm{fed}$, in the $1^{\text {st }}$ and $2^{\text {nd }}$ season, respectively (Table 2). The increase in cane height may be attributed to the role of nitrogen as an essential element in building-up plant organs and enhancing their growth. These results are similar to those obtained by El-Gedawwy, et al. (2012); Bekheet and Rania (2016) and Makhlouf et al. (2016).

Data in the same table revealed that millable cane height was gradually and significantly increased with increasing number of $\mathrm{N}$-doses from 2 to 4 in both seasons. These results may be referred to that increasing the splitting of N-level guaranteed the availability of nitrogen required by cane plants and decreased its loss by leaching by the surface irrigation beyond root system, which ensured better nutrition and positively reflected in better growth appearance. Similar trends were reported by Pannerselvam and Durai (2004); Nigadeet, al. (2006); Mokadem, et al. (2008) and Wubale and Girma (2018).

Millable cane height was significantly influenced by the interactions between the studied factors except for that between seed rate and number of $\mathrm{N}$-doses in the $1^{\text {st }}$ season and that of $\mathrm{N}$ levels $\mathrm{x}$ number of $\mathrm{N}$-doses in the $2^{\text {nd }}$ one (Table 2). Planting sugarcane by 2.0 rows with the application of $240 \mathrm{~kg} \mathrm{~N} / \mathrm{fed}$, divided into 4 doses, resulted in the longest millable cane, in the $1^{\text {st }}$ and $2^{\text {nd }}$ seasons.

\section{Millable cane diameter:}

Data in Table (3) indicated that reducing the used planting material to 1.0 row of cane cuttings ( 25200 buds/fed) significantly resulted in producing the thickest millable cane diameter, in both seasons, compared to those obtained in case of planting with 1.5 and 2.0 rows of cane setts ( 37800 and 50400 buds/fed, successively), in both seasons. These results may be attributed to the lower inter-plant competition among plants for light and nutrients, as well as little mutual shading in case of planting with the lowest seeding rate, which

Fayoum J. Agric. Res. \& Dev., Vol. 34, No.1, January, 2020 
resulted in the lowest plant population, in comparison to the other higher seed rates. These results are in harmony with those reported by Shalaby, et al. (2011) and Makhlouf, et al. (2016).

Millable cane diameter increased significantly when $\mathrm{N}$ level was raised from 180 up to $240 \mathrm{~kg} \mathrm{~N} /$ fed given to cane plants in the $1^{\text {st }}$ and $2^{\text {nd }}$ seasons (Table 3 ). These results may be attributed to the role of $\mathrm{N}$ element in building-up plant organs and enhancing plant growth. These results are in agreement with those reported by Osman, et al. (2010); El-Gedawwy, et al. (2012); Bekheet and Abd El-Aziz (2016) and Makhlouf, et al. (2016).

Table (2): Effect of seed rates, nitrogen levels, number of $N$ doses and their interactions on millable cane height $(\mathrm{cm})$ in $2016 / 2017$ and $2017 / 2018$ seasons

\begin{tabular}{|c|c|c|c|c|c|c|c|c|c|}
\hline \multirow{3}{*}{$\begin{array}{l}\text { Seed rate/fed } \\
\text { (A) }\end{array}$} & \multirow{3}{*}{\begin{tabular}{|c|} 
N level, \\
kg N/fed \\
(B)
\end{tabular}} & \multicolumn{4}{|c|}{$2016 / 2017$} & \multicolumn{4}{|c|}{$2017 / 2018$} \\
\hline & & \multicolumn{3}{|c|}{ Number of $N$ doses $(C)$} & \multirow{2}{*}{ Mean } & \multicolumn{3}{|c|}{ Number of $N$ doses $(C)$} & \multirow{2}{*}{ Mean } \\
\hline & & 2 doses & 3 doses & 4 doses & & 2 doses & 3 doses & 4 doses & \\
\hline \multirow{3}{*}{$\begin{array}{l}1.0 \text { Row } \\
\text { (25200 buds) }\end{array}$} & 180 & 299.37 & 301.93 & 305.70 & 302.33 & 296.63 & 300.60 & 303.53 & 300.26 \\
\hline & 210 & 307.70 & 314.13 & 316.87 & 312.90 & 305.67 & 308.07 & 311.30 & 308.34 \\
\hline & 240 & 317.50 & 321.57 & 324.80 & 321.29 & 312.87 & 315.63 & 317.47 & 315.99 \\
\hline Mean & & 308.19 & 312.54 & 315.79 & 312.17 & 305.06 & 308.10 & 311.43 & 308.20 \\
\hline \multirow{3}{*}{$\begin{array}{c}1.5 \text { row } \\
\text { (37800 buds) }\end{array}$} & 180 & 307.37 & 311.87 & 315.83 & 311.69 & 305.03 & 308.53 & 311.73 & 308.43 \\
\hline & 210 & 319.37 & 323.90 & 328.60 & 323.96 & 316.10 & 318.10 & 322.33 & 318.84 \\
\hline & 240 & 329.43 & 331.17 & 335.87 & 332.16 & 325.17 & 324.43 & 333.07 & \begin{tabular}{|l|}
328.89 \\
\end{tabular} \\
\hline Mean & & 318.72 & 322.31 & 326.77 & 322.60 & 315.43 & 318.36 & 322.38 & \begin{tabular}{|l|}
318.72 \\
\end{tabular} \\
\hline \multirow{3}{*}{$\begin{array}{c}2.0 \text { rows } \\
\text { (50400 buds) }\end{array}$} & 180 & 309.57 & 313.93 & 318.40 & 313.97 & 308.80 & 311.33 & 315.60 & 311.91 \\
\hline & 210 & 322.63 & 326.43 & 330.43 & 326.50 & 318.57 & 322.50 & 327.40 & 322.82 \\
\hline & 240 & 334.83 & 337.97 & 341.57 & 338.12 & 331.07 & 334.39 & 338.73 & 334.91 \\
\hline Mean & & 322.34 & 326.11 & 330.13 & 326.20 & 319.48 & 322.92 & 327.24 & 323.22 \\
\hline \multirow{3}{*}{$\begin{array}{c}\text { Average of } \mathbf{N} \text { - } \\
\text { levels }\end{array}$} & 180 & 305.43 & 309.24 & 313.31 & 309.33 & 303.49 & 306.82 & 310.29 & 306.87 \\
\hline & 210 & 316.57 & 321.49 & 325.30 & 321.12 & 313.44 & 316.22 & 320.34 & \begin{tabular}{|l|}
316.67 \\
\end{tabular} \\
\hline & 240 & 327.26 & 330.23 & 334.08 & 330.52 & 323.03 & 326.33 & 330.42 & 326.60 \\
\hline \multicolumn{2}{|l|}{ Mean of N doses } & 316.42 & 320.32 & 324.23 & & 313.32 & 316.46 & 320.35 & \\
\hline \multicolumn{10}{|c|}{ LSD at 0.5 level for: } \\
\hline \multicolumn{2}{|l|}{ Seed rate } & & 1.80 & $A \times C$ & NS & $\mathbf{A}$ & 0.49 & $A \times C$ & 0.60 \\
\hline \multicolumn{2}{|c|}{ Nitrogen level $\quad$ B } & & 0.63 & B $\times$ C & 0.75 & B & 0.77 & B $\times$ C & NS \\
\hline \multicolumn{3}{|c|}{ N-dose number $\mathrm{C}$} & 0.43 & $A x B x C$ & 1.36 & $\mathbf{C}$ & 0.35 & $\mathbf{A x B x C}$ & 1.04 \\
\hline \multicolumn{3}{|c|}{$A \times B$} & 1.09 & & & $\mathbf{A} \times \mathbf{B}$ & 1.34 & & \\
\hline
\end{tabular}

Data in Table (3) revealed that millable cane diameter was gradually increased with increasing number of $\mathrm{N}$-doses from 2 to 4 doses in both seasons. These results may be referred to that, more splitting of $\mathrm{N}$-level led to increase the availability of nitrogen as structural element for cane plants for longer time and decrease its loss by leaching as a result of using flooding irrigation, which ensures better nutrition and reflected in better growth performance. Similar trends were reported by Mokadem, et al. (2008) and Wubale and Girma (2018).

Fayoum J. Agric. Res. \& Dev., Vol. 34, No.1, January, 2020 
Millable cane diameter was significantly affected by the interactions between the studied factors in in both seasons (Table 3), except that of seed rate $\mathrm{x} N$ levels in the $1^{\text {st }}$ and $2^{\text {nd }}$ seasons. The highest millable cane thickness was obtained when sugarcane was planted using 1.0 row of 3-budded cuttings with the addition of 240 $\mathrm{kg} \mathrm{N} /$ fed divided into 4 doses, in both seasons.

Table (3): Effect of seed rates, nitrogen levels, number of $N$ doses and their interactions on millable cane diameter $(\mathrm{cm})$ in $2016 / 2017$ and $2017 / 2018$ seasons

\begin{tabular}{|c|c|c|c|c|c|c|c|c|c|}
\hline \multirow{3}{*}{$\begin{array}{l}\text { Seed rate/fed } \\
\text { (A) }\end{array}$} & \multirow{3}{*}{$\begin{array}{l}\text { N level, } \\
\text { kg N/fed } \\
\text { (B) }\end{array}$} & \multicolumn{4}{|c|}{$2016 / 2017$} & \multicolumn{4}{|c|}{$2017 / 2018$} \\
\hline & & \multicolumn{3}{|c|}{ Number of $N$ doses $(C)$} & \multirow{2}{*}{ Mean } & \multicolumn{3}{|c|}{ Number of $N$ doses $(C)$} & \multirow{2}{*}{ Mean } \\
\hline & & \begin{tabular}{|l|}
2 doses \\
\end{tabular} & 3 doses & 4 doses & & 2 doses & 3 doses & 4 doses & \\
\hline \multirow{3}{*}{$\begin{array}{c}1.0 \text { row } \\
\text { (25200 buds) }\end{array}$} & 180 & 2.51 & 2.53 & 2.55 & 2.53 & 2.47 & 2.49 & 2.51 & 2.49 \\
\hline & 210 & 2.56 & 2.57 & 2.60 & 2.58 & 2.53 & 2.55 & 2.57 & 2.55 \\
\hline & 240 & 2.61 & 2.63 & 2.65 & 2.63 & 2.59 & 2.61 & 2.63 & 2.61 \\
\hline Mean & & 2.56 & 2.58 & 2.60 & 2.58 & 2.53 & 2.55 & 2.57 & 2.55 \\
\hline \multirow{3}{*}{$\begin{array}{c}1.5 \text { row } \\
\text { (37800 buds) }\end{array}$} & 180 & 2.49 & 2.51 & 2.53 & 2.51 & 2.45 & 2.47 & 2.49 & 2.47 \\
\hline & 210 & 2.55 & 2.56 & 2.58 & 2.56 & 2.51 & 2.53 & 2.55 & 2.53 \\
\hline & 240 & 2.59 & 2.61 & 2.62 & 2.60 & 2.57 & 2.59 & 2.61 & 2.59 \\
\hline Mean & & 2.54 & 2.56 & 2.58 & 2.56 & 2.51 & 2.53 & 2.55 & 2.53 \\
\hline \multirow{3}{*}{$\begin{array}{c}2.0 \text { rows } \\
\text { (50400 buds) }\end{array}$} & 180 & 2.46 & 2.49 & 2.51 & 2.48 & 2.45 & 2.46 & 2.48 & 2.46 \\
\hline & 210 & 2.52 & 2.54 & 2.55 & 2.54 & 2.49 & 2.51 & 2.53 & 2.51 \\
\hline & 240 & 2.57 & 2.58 & 2.59 & 2.58 & 2.54 & 2.55 & 2.59 & 2.56 \\
\hline Mean & & 2.52 & 2.54 & 2.55 & 2.53 & 2.49 & 2.51 & 2.53 & 2.51 \\
\hline \multirow{3}{*}{$\begin{array}{c}\text { Average of } \mathrm{N} \text { - } \\
\text { levels }\end{array}$} & 180 & 2.48 & 2.51 & 2.53 & 2.51 & 2.46 & 2.48 & 2.50 & 2.48 \\
\hline & 210 & 2.54 & 2.56 & 2.58 & 2.56 & 2.51 & 2.53 & 2.55 & 2.53 \\
\hline & 240 & 2.59 & 2.61 & 2.62 & 2.61 & 2.56 & 2.58 & 2.61 & 2.59 \\
\hline Mean of $N$ doses & & 2.54 & 2.56 & 2.58 & & 2.51 & 2.53 & 2.55 & \\
\hline \multicolumn{10}{|c|}{ LSD at 0.5 level for: } \\
\hline Seed rate & A & & 0.004 & $A \times C$ & 0.009 & A & 0.008 & A $\times C$ & 0.012 \\
\hline Nitrogen level & B & & 0.005 & B x C & 0.009 & B & 0.009 & B X C & 0.012 \\
\hline \multirow{2}{*}{$\mathrm{N}$-dose number } & C & & 0.005 & AxBxC & 0.015 & C & 0.005 & AxBxC & 0.015 \\
\hline & $A \times B$ & & NS & & & A $\times$ B & NS & & \\
\hline
\end{tabular}

\section{Millable cane fresh weight:}

Data in Table (4) illustrate that reducing the used planting material to 1.0 row of cane cuttings (25200 buds/fed) significantly increased millable cane fresh weight, compared to those obtained in case of planting with 1.5 and 2.0 rows of cane setts (37800 and 50400 buds/fed, successively), in both seasons. These results may be referred to the lower competition among plants for growth factors as sun light, water and nutrients, grown under conditions of the lowest seed rate, which resulted in the thickest cane stalks (Table 2), compared to higher plant populations, emerged

Fayoum J. Agric. Res. \& Dev., Vol. 34, No.1, January, 2020 
in case of using higher seed rates. The results are in conformity with those of Makhlouf, et al. (2016).

Millable cane weight increased significantly when $\mathrm{N}$ level was raised from 180 up to $240 \mathrm{~kg} \mathrm{~N} / \mathrm{fed}$ in the $1^{\text {st }}$ and $2^{\text {nd }}$ seasons (Table 4). These results may be attributed to the role of $\mathrm{N}$ element in building-up plant organs and enhancing plant growth. These results are in agreement with those reported by El-Gedawwy, et al. (2012) and Makhlouf, et al. (2016).

Data in Table (4) pointed out that millable cane weight was gradually and markedly increased with increasing number of $\mathrm{N}$-doses from 2 to 3 and 4 doses, in both seasons. These results may be referred to that, more splitting of N-level led to increase the availability of nitrogen as structural element for cane plants for longer time and decrease its loss by leaching, which contributed to better growth performance. Similar trends were reported by Mokadem, et al. (2008) and Wubale and Girma (2018).

Millable cane weight was significantly affected by the interactions between the studied factors in both seasons. Planting sugarcane using 1.0 row of 3-budded cane cuttings with the addition of $240 \mathrm{~kg} \mathrm{~N} / \mathrm{fed}$, divided into 4-doses gave the highest millable cane weight, in the $1^{\text {st }}$ and $2^{\text {nd }}$ season.

\section{Brix percentage:}

Data in Table (5) revealed that decreasing seed rate to 1.0 row of cane cuttings (25200 buds/fed) used in sugarcane planting significantly increased brix\% compared to that planted with 1.5 or 2.0 drills of setts $(37800$ and 50400 buds/fed, respectively), in the $1^{\text {st }}$ and $2^{\text {nd }}$ seasons. These results may be due to the great competition among plants for light and nutrients as well as mutual shading compared in case of using high rate of seeds for planting. Solar radiation has an effect on brix\% and sucrose\% (Chang, 1974). These results are in agreement with those mentioned by Hasan, et al. (2009) and Shalaby, et al. (2011).

Data in Table (5) showed that increasing $\mathrm{N}$ fertilizer from 180 up to $210 \mathrm{~kg}$ $\mathrm{N} /$ fed significantly improved in brix\%, thereafter, it decreased with raising nitrogen fertilization level to $240 \mathrm{~kg} \mathrm{~N} / \mathrm{fed}$, in both seasons. These results may indicate that $210 \mathrm{~kg} \mathrm{~N} / \mathrm{fed}$ was the best dose recording the highest total soluble solids in cane juice, while the highest $\mathrm{N}$-level may directed cane plants for more vegetative growth rather than dry matter accumulation. These results are in line with those mentioned by Osman, et al. (2010) and El-Gedawwy, et al. (2012).

Fayoum J. Agric. Res. \& Dev., Vol. 34, No.1, January, 2020 
EFFECT OF LEVELS, DOSES OF NITROGEN

Table (4): Effect of seed rates, nitrogen levels, number of $N$ doses and their interactions on millable cane weight $(\mathrm{kg})$ in $2016 / 2017$ and $2017 / 2018$ seasons

\begin{tabular}{|c|c|c|c|c|c|c|c|c|c|}
\hline \multirow{3}{*}{$\begin{array}{l}\text { Seed rate/fed } \\
\text { (A) }\end{array}$} & \multirow{3}{*}{$\begin{array}{c}\text { N level, } \\
\text { kg N/fed } \\
\text { (B) }\end{array}$} & \multicolumn{4}{|c|}{$2016 / 2017$} & \multicolumn{4}{|c|}{$2017 / 2018$} \\
\hline & & \multicolumn{3}{|c|}{ Number of $N$ doses $(C)$} & \multirow{2}{*}{ Mean } & \multicolumn{3}{|c|}{ Number of $N$ doses $(C)$} & \multirow{2}{*}{ Mean } \\
\hline & & 2 doses & 3 doses & 4 doses & & 2 doses & 3 doses & 4 doses & \\
\hline \multirow{3}{*}{$\begin{array}{c}1.0 \text { row } \\
\text { (25200 buds) }\end{array}$} & 180 & 1.337 & 1.347 & 1.363 & 1.349 & 1.348 & 1.361 & 1.368 & 1.359 \\
\hline & 210 & 1.367 & 1.392 & 1.403 & 1.387 & 1.385 & 1.399 & 1.413 & 1.399 \\
\hline & 240 & 1.418 & 1.425 & 1.436 & 1.426 & 1.431 & 1.440 & 1.453 & 1.441 \\
\hline Mean & & 1.374 & 1.388 & 1.401 & 1.388 & 1.388 & 1.400 & 1.411 & 1.400 \\
\hline \multirow{3}{*}{$\begin{array}{c}1.5 \text { row } \\
\text { (37800 buds) }\end{array}$} & 180 & 1.326 & 1.340 & 1.345 & 1.337 & 1.334 & 1.342 & 1.353 & 1.343 \\
\hline & 210 & 1.358 & 1.369 & 1.389 & 1.372 & 1.358 & 1.370 & 1.382 & 1.370 \\
\hline & 240 & 1.403 & 1.413 & 1.416 & 1.411 & 1.403 & 1.410 & 1.419 & 1.411 \\
\hline $\mathbf{N}$ & & 1.363 & 1.374 & 1.383 & 1.373 & 1.365 & 1.374 & 1.385 & 1.375 \\
\hline \multirow{3}{*}{$\begin{array}{c}2.0 \text { rows } \\
(50400 \text { buds })\end{array}$} & 180 & 1.308 & 1.316 & 1.329 & 1.318 & 1.316 & 1.325 & 1.341 & 1.327 \\
\hline & 210 & 1.342 & 1.351 & 1.364 & 1.352 & 1.345 & 1.361 & 1.365 & 1.357 \\
\hline & 240 & 1.377 & 1.387 & 1.398 & 1.388 & 1.386 & 1.396 & 1.406 & 1.396 \\
\hline Mean & & 1.342 & 1.352 & 1.364 & 1.353 & 1.349 & 1.361 & 1.371 & 1.360 \\
\hline \multirow{3}{*}{$\begin{array}{c}\text { Average of } \mathrm{N} \text { - } \\
\text { levels }\end{array}$} & 180 & 1.324 & 1.335 & 1.346 & 1.350 & 1.332 & 1.343 & 1.354 & 1.343 \\
\hline & 210 & 1.356 & 1.370 & 1.385 & 1.371 & 1.363 & 1.376 & 1.387 & 1.375 \\
\hline & 240 & 1.399 & 1.409 & 1.417 & 1.408 & 1.407 & 1.415 & 1.426 & 1.416 \\
\hline Mean of $\mathrm{N}$ doses & & 1.360 & 1.371 & 1.383 & & 1.367 & 1.378 & 1.389 & \\
\hline \multicolumn{10}{|c|}{ LSD at 0.5 level for: } \\
\hline Seed rate & & $\mathbf{A}$ & 0.002 & $A \times C$ & 0.001 & $\mathbf{A}$ & 0.002 & A $\times$ C & 0.001 \\
\hline Nitrogen & level & B & 0.001 & B x C & 0.001 & B & 0.001 & B x C & 0.001 \\
\hline N-dose $n$ & umber & $\mathrm{C}$ & 0.001 & $\mathrm{AxBxC}$ & 0.003 & $\mathrm{C}$ & 0.001 & $\mathrm{AxBxC}$ & 0.002 \\
\hline & $\mathbf{x B}$ & & 0.002 & & & $A \times B$ & 0.001 & & \\
\hline
\end{tabular}

Fayoum J. Agric. Res. \& Dev., Vol. 34, No.1, January, 2020 
Table (5): Effect of seed rates, nitrogen levels, number of $\mathbf{N}$ doses and their interactions on brix \% in 2016/2017 and 2017/2018 seasons

\begin{tabular}{|c|c|c|c|c|c|c|c|c|c|}
\hline \multirow{3}{*}{$\begin{array}{l}\text { Seed rate/fed } \\
\text { (A) }\end{array}$} & \multirow{3}{*}{$\begin{array}{c}\text { N level, } \\
\text { kg N/fed } \\
\text { (B) }\end{array}$} & \multicolumn{4}{|c|}{$2016 / 2017$} & \multicolumn{4}{|c|}{ 2017/2018 } \\
\hline & & \multicolumn{3}{|c|}{ Number of $N$ doses $(C)$} & \multirow{2}{*}{ Mean } & \multicolumn{3}{|c|}{ Number of $N$ doses $(C)$} & \multirow{2}{*}{ Mean } \\
\hline & & 2 doses & 3 doses & 4 doses & & 2 doses & 3 doses & 4 doses & \\
\hline \multirow{3}{*}{$\begin{array}{c}1.0 \text { row } \\
(25200 \text { buds })\end{array}$} & 180 & 20.48 & 20.74 & 21.04 & 20.76 & 19.93 & 20.23 & 20.54 & 20.23 \\
\hline & 210 & 21.39 & 21.51 & 21.62 & 21.51 & 21.03 & 21.29 & 21.47 & 21.27 \\
\hline & 240 & 20.93 & 21.26 & 21.44 & 21.21 & 20.82 & 21.06 & 21.28 & 21.05 \\
\hline Mean & & 20.93 & 21.17 & 21.37 & 21.16 & 20.53 & 20.86 & 21.10 & 20.85 \\
\hline \multirow{3}{*}{$\begin{array}{c}1.5 \text { row } \\
\text { (37800 buds) }\end{array}$} & 180 & 20.40 & 20.64 & 20.98 & 20.67 & 19.79 & 20.17 & 20.45 & 20.14 \\
\hline & 210 & 21.22 & 21.35 & 21.48 & 21.35 & 20.85 & 21.13 & 21.36 & 21.11 \\
\hline & 240 & 20.82 & 21.13 & 21.31 & 21.09 & 20.62 & 20.88 & 21.08 & 20.86 \\
\hline Mean & & 20.82 & 21.04 & 21.26 & 21.04 & 20.42 & 20.73 & 20.96 & 20.70 \\
\hline \multirow{3}{*}{$\begin{array}{c}2.0 \text { rows } \\
\text { (50400 buds) }\end{array}$} & 180 & 20.18 & 20.41 & 20.65 & 20.41 & 19.56 & 19.91 & 20.18 & 19.88 \\
\hline & 210 & 21.21 & 21.28 & 21.39 & 21.30 & 20.64 & 20.88 & 21.14 & 20.89 \\
\hline & 240 & 20.79 & 21.08 & 21.22 & 21.03 & 20.53 & 20.69 & 20.94 & 20.72 \\
\hline Mean & & 20.73 & 20.92 & 21.09 & 20.91 & 20.24 & 20.49 & 20.75 & 20.50 \\
\hline \multirow{3}{*}{$\begin{array}{c}\text { Average of } \mathrm{N}- \\
\text { levels }\end{array}$} & 180 & 20.35 & 20.60 & 20.89 & 20.61 & 19.76 & 20.10 & 20.39 & 20.08 \\
\hline & 210 & 21.27 & 21.38 & 21.50 & 21.39 & 20.84 & 21.10 & 21.33 & 21.09 \\
\hline & 240 & 20.85 & 21.16 & 21.33 & 21.11 & 20.65 & 20.88 & 21.10 & 20.88 \\
\hline \multicolumn{2}{|l|}{ Mean of N doses } & 20.83 & 21.05 & 21.24 & & 20.42 & 20.69 & 20.94 & \\
\hline \multicolumn{10}{|c|}{ LSD at 0.5 level for: } \\
\hline \multicolumn{2}{|l|}{ Seeds rate } & & 0.07 & $A \times C$ & NS & $\mathbf{A}$ & 0.07 & $A \times C$ & NS \\
\hline \multirow{2}{*}{\multicolumn{3}{|c|}{$\begin{array}{ll}\text { Nitrogen levels } B \\
\text { Number of } \text { N doses }\end{array}$}} & 0.05 & B X C & 0.05 & B & 0.04 & $\mathbf{B} \times \mathbf{C}$ & 0.03 \\
\hline & & & 0.03 & $\mathbf{A x B x C}$ & 0.09 & $\mathbf{C}$ & 0.02 & $\mathbf{A x B x C}$ & NS \\
\hline \multicolumn{3}{|c|}{$A \times B$} & 0.09 & & & A $\times$ B & NS & & \\
\hline
\end{tabular}

Data in Tables (5) cleared that increasing the number of $\mathrm{N}$-doses to 4-doses resulted in a significant increase in brix \%, in both seasons. This result may be due to that increasing the splitting of N-level led to availability of nitrogen as an essential element used by cane plants and contributed to better growth and efficient dry matter accumulation. Similar results were reported by Mokadem, et al. (2008).

Brix\% was insignificantly affected by the interactions between the studied factors except that of seed rate $\mathrm{x} \mathrm{N}$ level in the $1^{\text {st }}$ season; seed rate $\mathrm{x}$ number of $\mathrm{N}$ dose, in both seasons as well as the $2^{\text {nd }}$ order interaction between the three factors, in the $2^{\text {nd }}$ season. The highest brix $\%$ was recorded by planting sugarcane using 1.0 row of 3-budded cane setts and adding $210 \mathrm{~kg} \mathrm{~N} /$ fed into 4-doses.

\section{Sucrose\%:}

Data in Table (6) showed that decreasing seed rate to 1.0 row of cane cuttings (25200 buds/fed) used in sugarcane planting significantly increased sucrose \% compared to that planted with 1.5 or 2.0 drills of setts $(37800$ and 50400 buds/fed,

Fayoum J. Agric. Res. \& Dev., Vol. 34, No.1, January, 2020 
respectively), in the $1^{\text {st }}$ and $2^{\text {nd }}$ seasons. These results are line with that shown by Hasan, et al. (2009).

Data in Table (6) showed that increasing $\mathrm{N}$ fertilizer from 180 up to $210 \mathrm{~kg}$ $\mathrm{N} /$ fed significantly improved in sucrose $\%$, thereafter, it decreased with raising nitrogen fertilization level to $240 \mathrm{~kg} \mathrm{~N} / \mathrm{fed}$, in both seasons. These results may indicate that $210 \mathrm{~kg} \mathrm{~N} / \mathrm{fed}$ was the best dose recording the highest sucrose in cane juice, while the highest N-level may directed cane plants for more vegetative growth rather than dry matter accumulation. These results are in line with those mentioned by Mokadem, et al. (2008) and El-Gedawwy, et al. (2012).

Data in Tables (6) clear that increasing the number of N-doses from 2 to 4 resulted a significant increase in sucrose $\%$ in both seasons. This result is similar to that of brix\% (Tables 5). This result may be due to that increasing the splitting of $\mathrm{N}$ level led to availability of nitrogen as an essential element to better growth and increase sucrose accumulation. Similar results were reported by Mokadem, et al. (2008).

Sucrose\% was significantly affected by the interactions between the studied factors except that of seed rate $\mathrm{x}$ number of $\mathrm{N}$ dose in the $1^{\text {st }}$ season; seed rate $\mathrm{x} \mathrm{N}$ level in the $2^{\text {nd }}$ season. The highest sucrose $\%$ was recorded by planting sugarcane using 1.0 row of 3-budded cane setts and adding $210 \mathrm{~kg} \mathrm{~N} /$ fed into 4-doses in both seasons.

\section{Sugar recovery \%:}

Data in Tables (7) revealed that decreasing seed rate to 1.0 row of cane cuttings (25200 buds/fed) used in sugarcane planting significantly increased sugar recovery\% compared to that planted with 1.5 or 2.0 drills of setts $(37800$ and 50400 buds/fed, respectively), in the $1^{\text {st }}$ and $2^{\text {nd }}$ seasons. Increasing in brix $\%$ and sucrose $\%$ (Tables 5 and 6) resulted in increased sugar recovery\%. These results are in agreement with those mentioned by Hasan, et al. (2009).

Fayoum J. Agric. Res. \& Dev., Vol. 34, No.1, January, 2020 
Table (6): Effect of seed rates, nitrogen levels, number of $N$ doses and their interactions on sucrose $\%$ in 2016/2017 and 2017/2018 seasons

\begin{tabular}{|c|c|c|c|c|c|c|c|c|c|}
\hline \multirow{3}{*}{$\begin{array}{l}\text { Seed rate/fed } \\
\text { (A) }\end{array}$} & \multirow{3}{*}{$\begin{array}{l}\text { N level, } \\
\text { kg N/fed } \\
\text { (B) }\end{array}$} & \multicolumn{4}{|c|}{ 2016/2017 } & \multicolumn{4}{|c|}{$2017 / 2018$} \\
\hline & & \multicolumn{3}{|c|}{ Number of $N$ doses $(C)$} & \multirow{2}{*}{ Mean } & \multicolumn{3}{|c|}{ Number of $N$ doses $(C)$} & \multirow{2}{*}{ Mean } \\
\hline & & 2 doses & 3 doses & 4 doses & & 2 doses & 3 doses & 4 doses & \\
\hline \multirow{3}{*}{$\begin{array}{l}1.0 \text { Row } \\
\text { (25200 buds) }\end{array}$} & 180 & 17.49 & 17.75 & 17.97 & 17.74 & 17.07 & 17.40 & 17.66 & 17.38 \\
\hline & 210 & 18.49 & 18.71 & 18.83 & 18.67 & 18.06 & 18.30 & 18.56 & 18.31 \\
\hline & 240 & 17.94 & 18.35 & 18.69 & 18.33 & 17.99 & 18.10 & 18.32 & 18.14 \\
\hline Mean & & 17.97 & 18.27 & 18.50 & 18.25 & 17.71 & 17.93 & 18.18 & 17.94 \\
\hline \multirow{3}{*}{$\begin{array}{c}1.5 \text { row } \\
\text { (37800 buds) }\end{array}$} & 180 & 17.37 & 17.63 & 17.85 & 17.62 & 16.84 & 17.33 & 17.73 & 17.31 \\
\hline & 210 & 18.36 & 18.56 & 18.65 & 18.52 & 17.94 & 18.19 & 18.41 & 18.18 \\
\hline & 240 & 17.86 & 18.14 & 18.53 & 18.18 & 17.80 & 18.00 & 18.18 & 18.00 \\
\hline Mean & & 17.86 & 18.11 & 18.34 & 18.11 & 17.53 & 17.84 & 18.11 & 17.83 \\
\hline \multirow{3}{*}{$\begin{array}{c}2.0 \text { rows } \\
\text { (50400 buds) }\end{array}$} & 180 & 17.21 & 17.46 & 17.67 & 17.45 & 16.65 & 17.14 & 17.55 & 17.11 \\
\hline & 210 & 18.29 & 18.48 & 18.47 & 18.41 & 17.83 & 18.02 & 18.28 & 18.04 \\
\hline & 240 & 17.75 & 18.07 & 18.39 & 18.07 & 17.69 & 17.81 & 18.09 & 17.87 \\
\hline Mean & & 17.75 & 18.00 & 18.18 & 17.98 & 17.39 & 17.66 & 17.97 & 17.67 \\
\hline \multirow{3}{*}{$\begin{array}{c}\text { Average of } \mathbf{N} \text { - } \\
\text { levels }\end{array}$} & 180 & 17.36 & 17.61 & 17.83 & 17.60 & 16.86 & 17.29 & 17.65 & 17.27 \\
\hline & 210 & 18.38 & 18.58 & 18.65 & 18.54 & 17.94 & 18.17 & 18.42 & 18.18 \\
\hline & 240 & 17.85 & 18.19 & 18.53 & 18.19 & 18.83 & 17.97 & 18.20 & 18.00 \\
\hline \multicolumn{2}{|l|}{ Mean of N doses } & $\mathbf{1 7 . 8 6}$ & 18.13 & 18.40 & & 17.54 & 17.81 & 18.09 & \\
\hline \multicolumn{10}{|c|}{ LSD at 0.5 level for: } \\
\hline \multicolumn{2}{|l|}{ Seeds rate } & & $\mathbf{0 . 0 7}$ & $A \times C$ & NS & $\mathbf{A}$ & 0.07 & $A \times C$ & 0.03 \\
\hline \multicolumn{3}{|c|}{$\begin{array}{ll}\text { Nitrogen levels } & \text { B } \\
\end{array}$} & 0.07 & $\mathrm{~B} \times \mathrm{C}$ & 0.06 & B & 0.03 & B $\times$ C & 0.03 \\
\hline \multicolumn{3}{|c|}{ Number of $\mathrm{N}$ doses $\mathrm{C}$} & 0.03 & $\mathbf{A x B x C}$ & 0.10 & $\mathbf{C}$ & 0.02 & $\mathbf{A x B x C}$ & 0.05 \\
\hline \multicolumn{3}{|c|}{ A $\times \mathbf{B}$} & 0.11 & & & $A \times B$ & NS & & \\
\hline
\end{tabular}

Data in Table (7) showed that increasing $\mathrm{N}$ fertilizer from 180 up to $210 \mathrm{~kg} \mathrm{~N} / \mathrm{fed}$ significantly improved in sugar recovery\%, thereafter, it decreased with raising nitrogen fertilization level to $240 \mathrm{~kg} \mathrm{~N} / \mathrm{fed}$, in both seasons. This result is similar to that of brix and sucrose \% (Tables 5 and 6), where it is known that sugar recovery\% depends mainly on sucrose content. Similar results were given by El-Gedawwy, et al. (2012).

Data in Tables (7) cleared that increasing the number of $\mathrm{N}$ - doses to 4-doses for cane plants resulted significant increase in sugar recovery\% in both seasons. The increase sugar recovery\% due to increase in brix \% and sucrose \% (Tables 5 and 6). Similar results were reported by Mokadem, et al. (2008).

Sugar recovery\% was significantly affected by the interactions between the studied factors except that the $2^{\text {nd }}$ order interaction between the three factors, in the $1^{\text {st }}$ season; seed rate $\mathrm{x} \mathrm{N}$ levels in the $2^{\text {nd }}$ season (Table 7 ). The highest sugar recovery\% was recorded by planting sugarcane using 1.0 row of 3-budded cane setts and adding $210 \mathrm{~kg} \mathrm{~N} /$ fed into 4-doses.

Fayoum J. Agric. Res. \& Dev., Vol. 34, No.1, January, 2020 
Table (7): Effect of seed rates, nitrogen levels, number of $N$ doses and their interactions on sugar recovery $\%$ in $2016 / 2017$ and $2017 / 2018$ seasons

\begin{tabular}{|c|c|c|c|c|c|c|c|c|c|}
\hline \multirow{3}{*}{$\begin{array}{c}\text { Seed rate/fed } \\
\text { (A) }\end{array}$} & \multirow{3}{*}{$\begin{array}{c}\text { N level, } \\
\text { kg N/fed } \\
(B)\end{array}$} & \multicolumn{4}{|c|}{$2016 / 2017$} & \multicolumn{4}{|c|}{$2017 / 2018$} \\
\hline & & \multicolumn{3}{|c|}{ Number of $N$ doses $(C)$} & \multirow{2}{*}{ Mean } & \multicolumn{3}{|c|}{ Number of $N$ doses $(C)$} & \multirow{2}{*}{ Mean } \\
\hline & & 2 doses & 3 doses & 4 doses & & 2 doses & 3 doses & 4 doses & \\
\hline \multirow{3}{*}{$\begin{array}{c}1.0 \text { row } \\
\text { (25200 buds) }\end{array}$} & 180 & 11.22 & 11.40 & 11.50 & 11.37 & 11.01 & 11.24 & 11.40 & 11.21 \\
\hline & 210 & 11.96 & 12.17 & 12.24 & 12.12 & 11.61 & 11.77 & 12.00 & 11.80 \\
\hline & 240 & 11.53 & 11.86 & 12.18 & 11.86 & 11.66 & 11.66 & 11.81 & 11.71 \\
\hline & & 11.57 & 11.81 & 11.97 & 11.78 & 11.42 & 11.56 & 11.74 & 11.57 \\
\hline \multirow{3}{*}{$\begin{array}{c}1.5 \text { row } \\
\text { (37800 buds) }\end{array}$} & 180 & 11.33 & 11.30 & 11.38 & 11.34 & 10.79 & 11.20 & 11.55 & 11.18 \\
\hline & 210 & 11.89 & 12.08 & 12.12 & 12.03 & 11.57 & 11.73 & 11.88 & 11.73 \\
\hline & 240 & 11.84 & 11.67 & 12.06 & 11.74 & 11.54 & 11.64 & 11.75 & 11.64 \\
\hline N & & 11.57 & 11.68 & 11.85 & 11.70 & 11.30 & 11.52 & 11.73 & 11.52 \\
\hline \multirow{3}{*}{$\begin{array}{c}2.0 \text { rows } \\
\text { (50400 buds) }\end{array}$} & 180 & 11.04 & 11.22 & 11.34 & 11.21 & 10.69 & 11.10 & 11.47 & 11.09 \\
\hline & 210 & 11.80 & 12.01 & 11.93 & 11.91 & 11.56 & 11.66 & 11.84 & 11.69 \\
\hline & 240 & 11.37 & 11.60 & 11.93 & 11.64 & 11.45 & 11.51 & 11.72 & 11.56 \\
\hline & & 11.41 & 11.61 & 11.74 & 11.74 & 11.23 & 11.42 & 11.68 & 11.44 \\
\hline \multirow{3}{*}{$\begin{array}{c}\text { Average of N- } \\
\text { levels }\end{array}$} & 180 & 11.20 & 11.31 & 11.41 & 11.30 & 10.83 & 11.18 & 11.47 & 11.16 \\
\hline & 210 & 11.88 & 12.01 & 12.10 & 12.02 & 11.58 & 11.72 & 11.91 & 11.74 \\
\hline & 240 & 11.46 & 11.71 & 12.06 & 11.74 & 11.55 & 11.60 & 11.76 & 11.64 \\
\hline \multicolumn{2}{|l|}{ Mean of N doses } & 11.51 & 11.70 & 11.85 & & 11.32 & 11.50 & 11.71 & \\
\hline \multicolumn{10}{|c|}{ LSD at 0.5 level for: } \\
\hline \multicolumn{2}{|l|}{ Seeds rate } & & 0.06 & $A \times C$ & 0.08 & $\mathbf{A}$ & 0.05 & $A \times C$ & $\mathbf{0 . 0 3}$ \\
\hline \multicolumn{2}{|c|}{ Nitrogen levels } & & 0.09 & $\mathbf{B} \times \mathbf{C}$ & 0.08 & B & 0.02 & $\mathbf{B} \times \mathbf{C}$ & $\mathbf{0 . 0 3}$ \\
\hline \multicolumn{3}{|c|}{ Number of $\mathrm{N}$ doses $\mathrm{C}$} & 0.05 & AxBxC & NS & $\mathbf{C}$ & 0.02 & $\mathbf{A x B x C}$ & 0.05 \\
\hline \multicolumn{3}{|c|}{$\mathbf{A} \times \mathbf{B}$} & 0.14 & & & $A \times B$ & NS & & \\
\hline
\end{tabular}

\section{Number of millable canes/fed:}

Data in Table (8) cleared that the used seed rates significantly affected number of millable canes/fed, in both seasons. Planting sugarcane using 2.0 rows of cane cuttings (50400 buds/fed) increased number of millable canes/fed by 4.429 and 2.244 thousand/fed, compared to that planted with 1.0 and 1.5 drills of setts $(25200$ and 37800 buds/fed, respectively), in the $1^{\text {st }}$ season, being 4.877 and 2.086 thousand/fed in the $2^{\text {nd }}$ one. The increase of number of millable cane/fed may be due to the increase in population of cane plants emerged and utilized the available growth factors as space, sun light, water and nutrients. These results are in harmony with those reported by Ismail, et al. (2008); Shalaby, et al. (2011); El-Geddawy, et al (2015); Bekheet and Abd El-Aziz (2016) and Makhlouf, et al. (2016).

Significant increases of 0.825 and 1.585 millable canes/fed were gained by increasing the applied $\mathrm{N}$ levels to 210 and $240 \mathrm{~kg} \mathrm{~N} / \mathrm{fed}$ the $1^{\text {st }}$ season, respectively, compared with that recorded by applying $180 \mathrm{~kg}$ N/fed. Similarly, increases of 0.853

Fayoum J. Agric. Res. \& Dev., Vol. 34, No.1, January, 2020 
Ahmed F.I. Gadallah

and 1.683 millable canes/fed were obtained, in the $2^{\text {nd }}$ season (Table 8). These results are similar with those obtained by Osman, et al. (2010); El-Gedawwy, et al. (2012); Bekheet and Abd El-Aziz (2016) and Makhlouf, et al. (2016).

In the same table, it can be noticed that the number of millable canes/fed increased significantly with the increase in the number of $\mathrm{N}$-doses from 2 to 4 doses, in both seasons. These results may be due to the fact that increasing fractionation of $\mathrm{N}$ level contributes to the continuous availability of $\mathrm{N}$ as an essential element for cane plants, ensuring better nourishment, especially at tillering stage, which positively reflected on the harvested millable canes. Similar trend was reported by Mokadem, et al. (2008).

Number of millable canes/fed was significantly affected by the interactions between the studied factors in both seasons. Planting sugarcane by 2.0 rows with the addition of $240 \mathrm{~kg} \mathrm{~N} / \mathrm{fed}$, divided into 4-doses gave the highest number of millable canes/fed in the $1^{\text {st }}$ and $2^{\text {nd }}$ season.

Table (8): Effect of seed rates, nitrogen levels, number of $N$ doses and their interactions on number of millable canes (thousand/fed) in 2016/2017 and 2017/2018 seasons

\begin{tabular}{|c|c|c|c|c|c|c|c|c|c|}
\hline \multirow{3}{*}{$\begin{array}{l}\text { Seed rate/fed } \\
\text { (A) }\end{array}$} & \multirow{3}{*}{$\begin{array}{c}\text { N level, } \\
\text { kg N/fed } \\
\text { (B) }\end{array}$} & \multicolumn{4}{|c|}{$2016 / 2017$} & \multicolumn{4}{|c|}{$2017 / 2018$} \\
\hline & & \multicolumn{3}{|c|}{ Number of $N$ doses $(C)$} & \multirow{2}{*}{ Mean } & \multicolumn{3}{|c|}{ Number of $N$ doses $(C)$} & \multirow{2}{*}{ Mean } \\
\hline & & 2 doses & 3 doses & 4 doses & & 2 doses & 3 doses & 4 doses & \\
\hline \multirow{3}{*}{$\begin{array}{c}1.0 \text { row } \\
\text { (25200 buds) }\end{array}$} & 180 & 39.457 & 39.887 & 40.155 & 39.833 & 39.357 & 39.718 & 39.983 & 39.686 \\
\hline & 210 & 40.543 & 40.880 & 41.183 & 40.869 & 40.248 & 40.587 & 40.940 & 40.592 \\
\hline & 240 & 41.453 & 41.793 & 42.015 & 41.754 & 41.170 & 41.493 & 41.807 & 41.490 \\
\hline Mean & & 40.484 & 40.853 & 41.118 & 40.819 & 40.258 & 40.599 & 40.910 & 40.589 \\
\hline \multirow{3}{*}{$\begin{array}{c}1.5 \text { row } \\
\text { (37800 buds) }\end{array}$} & 180 & 42.397 & 42.620 & 42.860 & 42.626 & 42.310 & 42.573 & 42.877 & 42.587 \\
\hline & 210 & 43.058 & 43.333 & 43.580 & 43.324 & 43.055 & 43.390 & 43.753 & 43.399 \\
\hline & 240 & 43.772 & 43.943 & 44.190 & 43.968 & 43.970 & 44.140 & 44.350 & 44.153 \\
\hline Mean & & 43.076 & 43.299 & 43.543 & 43.306 & 43.112 & 43.368 & 43.660 & 43.380 \\
\hline \multirow{3}{*}{$\begin{array}{c}2.0 \text { rows } \\
\text { (50400 buds) }\end{array}$} & 180 & 44.243 & 44.577 & 44.800 & 44.540 & 44.320 & 44.652 & 44.910 & 44.627 \\
\hline & 210 & 44.993 & 45.313 & 45.533 & 45.280 & 45.178 & 45.417 & 45.807 & 45.467 \\
\hline & 240 & 45.780 & 46.000 & 46.317 & 46.032 & 46.083 & 46.297 & 46.533 & 46.304 \\
\hline Mean & & 45.006 & 45.279 & 45.550 & 45.284 & 45.194 & 45.455 & 45.750 & 45.466 \\
\hline \multirow{3}{*}{$\begin{array}{c}\text { Average of } \mathbf{N} \text { - } \\
\text { levels }\end{array}$} & 180 & 42.032 & 42.361 & 42.605 & 42.333 & 41.996 & 42.314 & 42.590 & 42.300 \\
\hline & 210 & 42.865 & 43.176 & 43.432 & 43.158 & 42.827 & 43.131 & 43.500 & 43.153 \\
\hline & 240 & 43.668 & 43.912 & 44.174 & 43.918 & 43.741 & 43.977 & 44.230 & 43.983 \\
\hline \multicolumn{2}{|l|}{ Mean of N doses } & 42.855 & 43.150 & 43.404 & & 42.855 & 43.141 & 43.440 & \\
\hline \multicolumn{10}{|c|}{ LSD at 0.5 level for: } \\
\hline \multicolumn{2}{|l|}{ Seeds rate } & & 0.031 & $A \times C$ & 0.028 & $\mathbf{A}$ & 0.019 & $A \times C$ & 0.024 \\
\hline \multicolumn{2}{|c|}{ Nitrogen levels } & & 0.023 & B x C & 0.028 & B & 0.015 & $\mathbf{B} \times \mathbf{C}$ & 0.024 \\
\hline \multicolumn{3}{|c|}{ Number of $\mathrm{N}$ doses $\mathrm{C}$} & 0.016 & $A x B x C$ & 0.049 & $\mathbf{C}$ & 0.014 & $A x B x C$ & 0.042 \\
\hline & & & 0.039 & & & A $\times$ B & 0.026 & & \\
\hline
\end{tabular}

Fayoum J. Agric. Res. \& Dev., Vol. 34, No.1, January, 2020 


\section{Cane yield/fed:}

Data in Table (9) showed that the used seed rates significantly affected cane yield /fed, in both seasons. Planting sugarcane using 2.0 rows of cane cuttings (50400 buds/fed) increased cane yield by 4.267 and 1.629 tons/fed, compared to that planted with 1.0 or 1.5 drills of setts ( 25200 and 37800 buds/fed, successively), in the $1^{\text {st }}$ season, corresponding to 4.648 and 2.085 tons of canes/fed, in the $2^{\text {nd }}$ one. These results could be due to the increase in number of millable canes/fed (Table 8 ). These results are in accordance with those reported by Shalaby, et al. (2011); ElGeddawy, et al. (2015); Bekheet and Abd El-Aziz (2016) and Makhlouf, et al. (2016).

The results showed that $\mathrm{N}$ levels significantly affected cane yield (tons/fed), in both seasons. Increasing $\mathrm{N}$ levels to $240 \mathrm{~kg} \mathrm{~N} / \mathrm{fed}$ increased cane yield by 5.223 and 2.635 tons/fed, compared with that obtained by adding 180 and $210 \mathrm{~kg} \mathrm{~N} / \mathrm{fed}$, in the $1^{\text {st }}$ season, respectively, corresponding to 5.320 and 2.862 tons/fed, in the $2^{\text {nd }}$ one (Table 9). These results are probably due to the increase in all of cane height, diameter and millable cane weight as well as number of millable canes/fed (Tables 2, 3, 4 and 8, respectively). These results are in a line with those reported Osman, et al. (2010); El-Gedawwy, et al. (2012); Bekheet and Abd El-Aziz (2016) and Makhlouf, et al. (2016).

Increasing dividing the amount of $\mathrm{N}$ fertilizer up to 4-doses significantly increased cane yield /fed by (1.700 and 0.825 ton/fed) and (1.700 and 0.857 ton/fed), compared to applying it at 2 and/or 3 doses, in the $1^{\text {st }}$ and $2^{\text {nd }}$ season, successively. These results were probably attributed to the increase in all of cane height, diameter and millable cane weight as well as number of millable canes/fed (Tables 2, 3, 4 and 8, respectively). Similar trends were reported by Pannerselvam and Durai (2004); Nigade, et al. (2006); Mokadem, et al. (2008) and Wubale and Girma (2018).

Cane yield was significantly affected by the interactions between the studied factors in both seasons (Table 9). The greatest cane yield/fed was obtained by planting sugarcane using 2.0 rows of 3-budded cane cuttings, and fertilizing sugarcane plants with $240 \mathrm{~kg} \mathrm{~N} / \mathrm{fed}$, divided into 4-equal doses, in both seasons.

\section{Sugar yield/fed:}

Data in Table (10) manifested that planting sugarcane using 2.0 rows of cane cuttings (50400 buds/fed) significantly increased sugar yield/fed by 0.386 and 0.124 ton/fed compared to that planted with 1.0 and 1.5 drills of setts (25200 and 37800 buds/fed, respectively), in the $1^{\text {st }}$ season, corresponding to 0.461 and 0.194 ton/fed, in the $2^{\text {nd }}$ one. The increase in sugar yield/fed was associated with the increase in cane yield/fed (Table 9), which is considered the main component of sugar yield. These results are in accordance with those reported by Ismail, et al. (2008); Hasan, et al. (2009); Shalaby, et al. (2011); El-Geddawy, et al. (2015); Bekheet and Abd El-Aziz (2016) and Makhlouf, et al. (2016).

Fayoum J. Agric. Res. \& Dev., Vol. 34, No.1, January, 2020 
Sugar yield was significantly increased by 0.848 and 0.155 ton/fed in the $1^{\text {st }}$ season, and 0.872 and 0.276 ton/fed, in the $2^{\text {nd }}$ one, when sugarcane was fertilized with $240 \mathrm{~kg} \mathrm{~N} / \mathrm{fed}$, compared to that supplied with 180 and/or $210 \mathrm{~kg} \mathrm{~N} / \mathrm{fed}$, respectively (Table 10). These results were fairly attributed to the increase in cane yield/fed, which showed the same trend in response to the application of the highest N-level. Similar results were given by Osman, et al. (2010); El-Gedawwy, et al. (2012); Bekheet and Abd El-Aziz (2016) and Makhlouf, et al (2016).

Sugar yield significantly and positively increased as the number of $\mathrm{N}$-doses increased from 2 up to 4-doses, in both seasons (Table 10). These results can be attributed to the same tendency of cane yield/fed and sugar recovery $\%$ in response to increasing the fractioning of $\mathrm{N}$ level (Tables 7 and 9), where cane yield and sugar content is the corner stone in the produced sugar yields. Similar trends were reported by Mokadem, et al. (2008) and Wubale and Girma (2018).

Sugar yield was significantly affected by the interactions between the studied factors in both seasons, except that between seeds rate and $\mathrm{N}$ levels and the $2^{\text {nd }}$ order interaction in the $1^{\text {st }}$ season (Table 10). The highest sugar production/fed was obtained by planting sugarcane variety vz. G.2003-47 (Giza 4) using 2.0 rows of 3budded cane seeds and fertilizing it with $240 \mathrm{~kg} \mathrm{~N} / \mathrm{fed}$, divided into 4-equal doses, in both seasons.

\section{CONCLUSION}

Under conditions of this work, it was found that growing Giza-4 sugarcane variety using 2.0 rows of cane setts (50400 buds/fed), fertilized with $240 \mathrm{~kg}$ N/fed divided into 4-equal doses can be recommended to get the maximum cane and sugar yields/fed in Sohag. 
EFFECT OF LEVELS, DOSES OF NITROGEN

Table (9): Effect of seed rates, nitrogen levels, number of $N$ doses and their interactions on cane yield (ton/fed) in 2016/2017 and 2017/2018 seasons

\begin{tabular}{|c|c|c|c|c|c|c|c|c|c|}
\hline \multirow{3}{*}{$\begin{array}{l}\text { Seed rate/fed } \\
\text { (A) }\end{array}$} & \multirow{3}{*}{$\begin{array}{c}\text { N level, } \\
\mathrm{kg} \text { N/fed } \\
(\mathrm{B})\end{array}$} & \multicolumn{4}{|c|}{$2016 / 2017$} & \multicolumn{4}{|c|}{$2017 / 2018$} \\
\hline & & \multicolumn{3}{|c|}{ Number of $N$ doses $(C)$} & \multirow{2}{*}{ Mean } & \multicolumn{3}{|c|}{ Number of $N$ doses $(C)$} & \multirow{2}{*}{ Mean } \\
\hline & & 2 doses & 3 doses & 4 doses & & 2 doses & 3 doses & 4 doses & \\
\hline \multirow{3}{*}{$\begin{array}{c}1.0 \text { row } \\
\text { (25200 buds) }\end{array}$} & 180 & 49.781 & 50.749 & 51.720 & 50.750 & 50.088 & 51.091 & 51.712 & 50.964 \\
\hline & 210 & 52.382 & 53.825 & 54.705 & 53.638 & 52.739 & 53.723 & 54.764 & 53.742 \\
\hline & 240 & 55.672 & 56.435 & 57.168 & 56.425 & 55.840 & 56.625 & 57.610 & 56.691 \\
\hline Mean & & 52.612 & 53.670 & 54.531 & 53.604 & 52.889 & 53.813 & 54.695 & 53.799 \\
\hline \multirow{3}{*}{$\begin{array}{c}1.5 \text { row } \\
\text { (37800 buds) }\end{array}$} & 180 & 53.052 & 53.914 & 54.446 & 53.804 & 53.253 & 53.940 & 54.811 & 54.001 \\
\hline & 210 & 55.258 & 56.059 & 57.264 & 56.194 & 55.225 & 56.190 & 57.186 & 56.200 \\
\hline & 240 & 58.129 & 58.796 & 59.259 & 58.728 & 58.378 & 58.942 & 59.606 & 58.975 \\
\hline Mean & & 55.480 & 56.256 & 56.990 & 56.242 & 55.619 & 56.357 & 57.201 & 56.392 \\
\hline \multirow{3}{*}{$\begin{array}{c}2.0 \text { rows } \\
\text { (50400 buds) }\end{array}$} & 180 & 54.537 & 55.334 & 56.179 & 55.350 & 54.986 & 55.829 & 56.871 & 55.896 \\
\hline & 210 & 57.007 & 57.820 & 58.692 & 57.840 & 57.376 & 58.391 & 59.106 & 58.291 \\
\hline & 240 & 59.606 & 60.367 & 61.292 & 60.422 & 60.400 & 61.142 & 61.920 & 61.154 \\
\hline Mean & & $\mathbf{5 7 . 0 5 0}$ & 57.841 & 58.721 & 57.871 & $\mathbf{5 7 . 5 8 8}$ & 58.454 & 59.299 & 58.447 \\
\hline \multirow{3}{*}{$\begin{array}{c}\text { Average of } \mathrm{N} \text { - } \\
\text { levels }\end{array}$} & 180 & 52.457 & 53.333 & 54.115 & 53.302 & 52.776 & 53.620 & 54.464 & 53.620 \\
\hline & 210 & 54.882 & 55.901 & 56.887 & 55.890 & 55.113 & 56.101 & 57.019 & 56.078 \\
\hline & 240 & 57.802 & 58.533 & 59.240 & 58.525 & 58.206 & 58.903 & 59.712 & 58.940 \\
\hline \multicolumn{2}{|l|}{ Mean of N doses } & 55.047 & 55.922 & 56.747 & & 55.365 & 56.208 & 57.065 & \\
\hline \multicolumn{10}{|c|}{ LSD at 0.5 level for: } \\
\hline \multicolumn{2}{|l|}{ Seed rate } & & 0.064 & $A \times C$ & 0.059 & $\mathbf{A}$ & 0.059 & $A \times C$ & 0.058 \\
\hline \multicolumn{2}{|c|}{ Nitrogen level $\quad$ B } & & 0.047 & B x C & 0.059 & B & 0.040 & B x C & 0.058 \\
\hline \multirow{2}{*}{\multicolumn{2}{|c|}{ N-dose number }} & & 0.034 & $A \times B \times C$ & 0.103 & $\mathbf{C}$ & 0.036 & $\mathbf{A x B x C}$ & 0.100 \\
\hline & & B & 0.082 & & & A $\times$ B & 0.069 & & \\
\hline
\end{tabular}

Fayoum J. Agric. Res. \& Dev., Vol. 34, No.1, January, 2020 
Table (10): Effect of seed rates, nitrogen levels, number of $N$ doses and their interactions on sugar yield/fed (ton) in 2016/2017 and 2017/2018 seasons

\begin{tabular}{|c|c|c|c|c|c|c|c|c|c|}
\hline \multirow{3}{*}{$\begin{array}{c}\text { Seed rate/fed } \\
\text { (A) }\end{array}$} & \multirow{3}{*}{$\begin{array}{l}\text { N level, } \\
\mathrm{kg} \text { N/fed } \\
\text { (B) }\end{array}$} & \multicolumn{4}{|c|}{$2016 / 2017$} & \multicolumn{4}{|c|}{$2017 / 2018$} \\
\hline & & \multicolumn{3}{|c|}{ Number of $N$ doses $(C)$} & \multirow{2}{*}{ Mean } & \multicolumn{3}{|c|}{ Number of $N$ doses $(C)$} & \multirow{2}{*}{ Mean } \\
\hline & & 2 doses & 3 doses & \begin{tabular}{|l|l|} 
doses \\
\end{tabular} & & 2 doses & 3 doses & 4 doses & \\
\hline \multirow{3}{*}{$\begin{array}{c}1.0 \text { row } \\
\text { (25200 buds) }\end{array}$} & 180 & 5.584 & 5.783 & 5.947 & 5.771 & 5.512 & 5.744 & 5.893 & 5.716 \\
\hline & 210 & 6.262 & 6.551 & 6.696 & 6.503 & 6.124 & 6.325 & 6.573 & 6.341 \\
\hline & 240 & 6.418 & 6.695 & 6.965 & 6.693 & 6.509 & 6.602 & 6.804 & 6.638 \\
\hline Mean & & 6.088 & 6.343 & 6.536 & 6.322 & 6.048 & 6.224 & 6.423 & 6.232 \\
\hline \multirow{3}{*}{$\begin{array}{c}1.5 \text { row } \\
\text { (37800 buds) }\end{array}$} & 180 & 6.013 & 6.090 & 6.198 & 6.100 & 5.747 & 6.040 & 6.330 & 6.039 \\
\hline & 210 & 6.570 & 6.770 & 6.938 & 6.759 & 6.389 & 6.590 & 6.793 & 6.591 \\
\hline & 240 & 6.676 & 6.861 & 7.145 & 6.894 & 6.735 & 6.860 & 7.003 & 6.866 \\
\hline & & 6.420 & 6.574 & 6.760 & 6.584 & 6.291 & 6.497 & 6.708 & 6.499 \\
\hline \multirow{3}{*}{$\begin{array}{c}2.0 \text { rows } \\
\text { (50400 buds) }\end{array}$} & 180 & 6.023 & 6.210 & 6.375 & 6.203 & 5.880 & 6.195 & 6.524 & 6.271 \\
\hline & 210 & 6.728 & 6.942 & 7.002 & 6.890 & 6.631 & 6.808 & 6.997 & 6.467 \\
\hline & 240 & 6.778 & 7.004 & 7.313 & 7.032 & 6.914 & 7.036 & 7.254 & 6.686 \\
\hline Mean & & 6.510 & 6.719 & 6.897 & 6.708 & 6.475 & 6.680 & 6.925 & 6.693 \\
\hline \multirow{3}{*}{$\begin{array}{c}\text { Average of N- } \\
\text { levels }\end{array}$} & 180 & 5.873 & 6.028 & 6.173 & 6.025 & 5.713 & 5.993 & 6.249 & 5.985 \\
\hline & 210 & 6.520 & 6.754 & 6.878 & 6.718 & 6.382 & 6.575 & 6.688 & 6.581 \\
\hline & 240 & 6.624 & 6.853 & 7.141 & 6.873 & 6.719 & 6.833 & 7.020 & 6.857 \\
\hline \multicolumn{2}{|c|}{ Mean of N doses } & 6.339 & 6.545 & 6.731 & & 6.271 & 6.467 & 6.686 & \\
\hline \multicolumn{10}{|c|}{ LSD at 0.5 level for: } \\
\hline Seed rate & $\vec{A}$ & & 0.031 & $A \times C$ & 0.046 & $\mathbf{A}$ & $\mathbf{0 . 0 2 3}$ & $\mathbf{A} \times \mathbf{C}$ & 0.019 \\
\hline \multicolumn{2}{|c|}{ Nitrogen level } & & 0.041 & B x C & 0.046 & $\mathbf{B}$ & 0.014 & B x C & 0.019 \\
\hline \multirow{2}{*}{\multicolumn{2}{|c|}{$\mathrm{N}$-dose number }} & & 0.027 & $\mathrm{AxBxC}$ & NS & $\mathrm{C}$ & 0.011 & $\mathrm{AxBxC}$ & 0.032 \\
\hline & & & NS & & & A $\times$ B & 0.025 & & \\
\hline
\end{tabular}

\section{REFERENCES}

Anonymous (1981). Chemical control in Egyptian sugar production factories. Jan., pp. 232.

A.O.A.C. (2005). Association of Official Analytical Chemists. Official methods of analysis, $26^{\text {th }}$ Ed. A.O.A.C., Int., Washington, D.C; USA.

Bekheet, M.A. and Rania M. Abd El-Aziz (2016). Effect of row spacing, seed rate and nitrogen fertilization on yield and quality of sugarcane. J. Biol. Chem. Envirorn. Sci., 11(3): 605-619.

Chang, J.H. (1974). Reparation balance. Climate and Agric. Aldine Publ. Co., Chicago, Illinois: 4-22.

El-Geddawy, I.H. Dalia.; B.S.I. Makhlouf and M.A. Bekheet (2015). Performance of some sugarcane promising varieties under different seed sett rates and potassium fertilization Int. J. Curr. Microbiol. App. Sci., 4 (11): 92-110.

El-Geddawy, I.H.; K.A.O. El-Aref; M.M. Ibrahim and A.M.K. Ali (2012). Performance of some sugarcane varieties under nitrogen fertilization of sugarcane Saccharum

Fayoum J. Agric. Res. \& Dev., Vol. 34, No.1, January, 2020 
officinarum L. to the plant levels and harvesting dates. Egypt. J. Appl. Sci., 27 (12): 520539.

Freed, R.S.P.; S.P. Eisensmith; S. Goetez; D. Recosky; V.W. Smail and P. Wolberg (1989). User's Guide MSTAT-C Software program for the design management and analysis of agronomic research experiments. Michigan State Univ., USA.

Gomez, K.A. and A.A. Gomez (1984). Statistical Procedures for Agricultural Research. John Willey and Sons. Inc., New York.

Hasan, H.F.M.; Maha M. El-Zeny and Ranya M. Abd El-Aziz (2009). Yield and quality relation to seed rates of some sugar cane varieties. J. Agric. Sci., Mansoura Univ., 34 (12): 11197-11206.

Ismail, A.M.A.; M.A. Bekheet and A.S. Abo El-Hamd (2008). Yield and quality of four sugarcane varieties as influenced by seed rate and nitrogen fertilization. Egypt. J. Appl. Sci., 23 (1): 107-123.

Makhlouf, B.S.I.; Dalia I.H. EI-Geddawy and A.E. Mohamed (2016). Performance evaluation of three sugarcane varieties under different levels of nitrogen fertilization and two seeding rates. Assiut J. Agric. Sci., 47 (5): 12-36.

Mokadem, Sh.A.; S.A.A. Atallah; M.A. Bekheet and A.F.I. Gadalla (2008). Effect of sources, levels and number of applications of nitrogen fertilizer on yield and quality of sugarcane. Minia J. Agric. Res., Develop., 28 (4): 767-783.

Nigade, R.D.; U.A. Kadam and B.S. Jadhav (2006). Response of sugarcane varieties to the time of fertilizer application and earthling up. Ind. Coop. Sugar, 38 (3): 3134.

Osman, A.M.H.; E.F.A. Aly and Ranya M. Abdel Aziz (2010). Effect of nitrogen fertilization levels on the performance of three promising sugar cane varieties under two different locations. Egypt. J. Appl. Sci., 25 (9): 453-463.

Pannerselvam, R. and R. Durai (2004). Studies on planting techniques and intercrops in sugarcane under levels and times of nitrogen application. Ind. Coop. Sugar, 35 (11): 857-860.

Shalaby, N.M.E.; A.M.H. Osman and Ranya M. Abdel Aziz (2011). Effect of seed rates and nitrogen fertilization levels on yield and quality of sugarcane. J. Plant Prod., Mansoura Univ., 2 (2): 279-287.

Yadav, R.L. and R.K. Sharma (1980). Effect of nitrogen level and harvesting date on quality characteristics and yield of four sugar cane genotypes. Indian J Agric Sci 50: 581-589.

Wubale, T. and A. Girma (2018). Effect of rate and time of nitrogen application on growth and quality of seed cane produced from tissue cultured plantlets at Tana Beles sugar development project, Ethiopia. Int. J. Compr. Res. Biol., Sci, 5 (3): 23-32.

Fayoum J. Agric. Res. \& Dev., Vol. 34, No.1, January, 2020 


\section{تأثثر مستويات وعدد جرعات السماد النيتروجينى ومعدلات التقاوى على حاصل وجودة قصب السكر

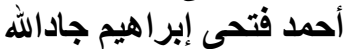 معهد بحوث المحاصيل السكرية ـ مركز البحوث الزيم جادراعية ـ الجيزة ـ مصر}

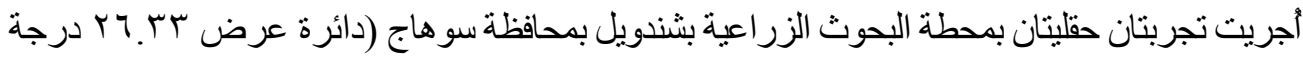

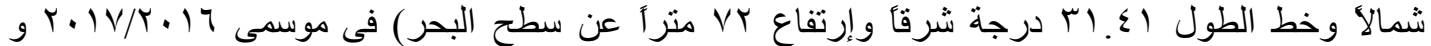

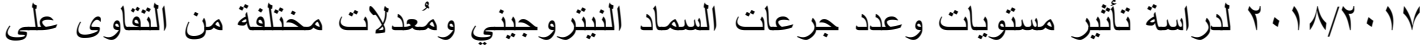

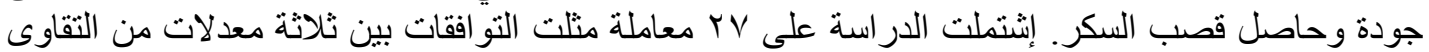

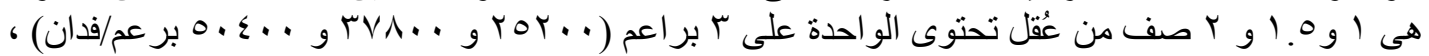

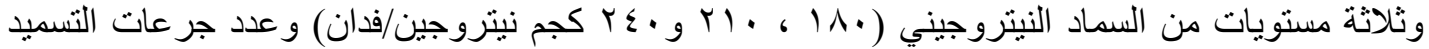

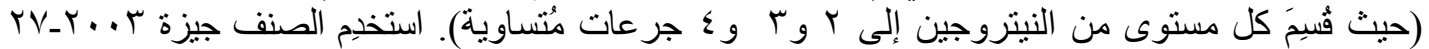

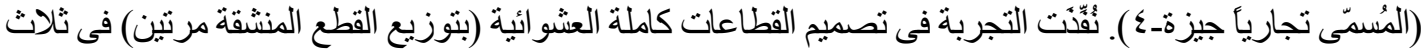

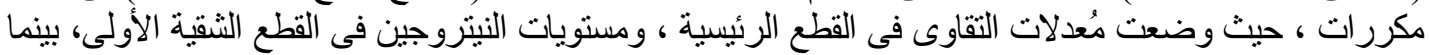

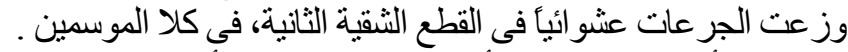

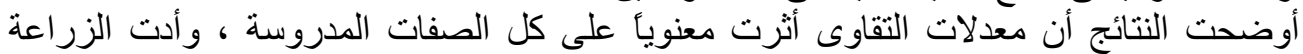

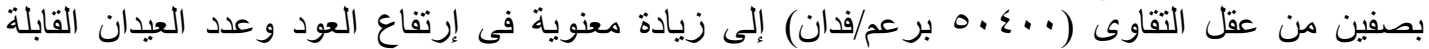

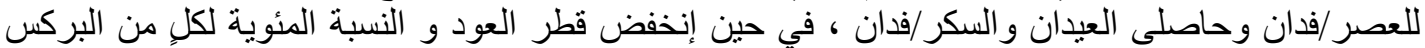

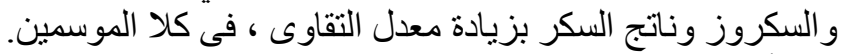

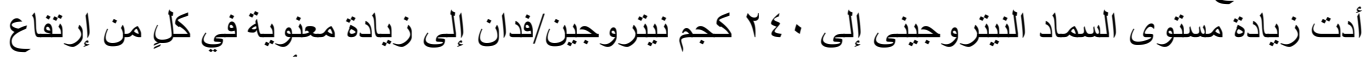

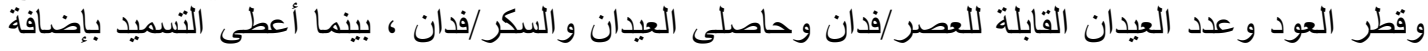

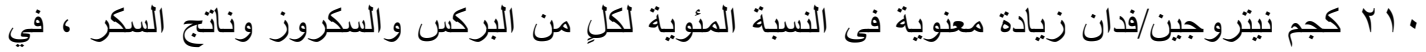

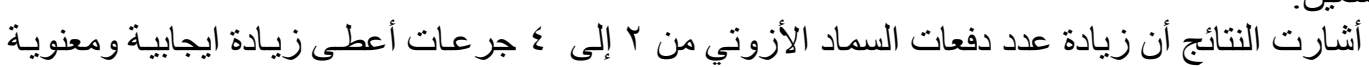

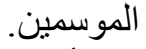

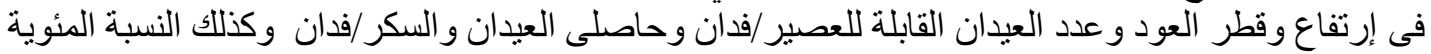

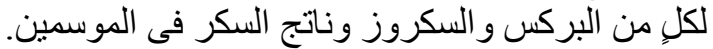

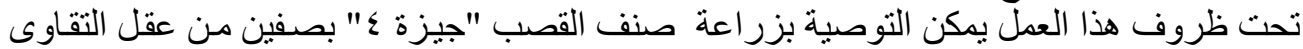

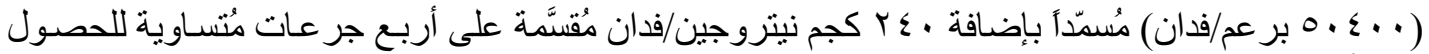

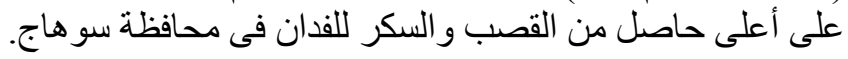

Fayoum J. Agric. Res. \& Dev., Vol. 34, No.1, January, 2020 